УДК 378.147:543:615:37.018.43

DOI 10.11603/me.2414-5998.2019.4.10860

I. Б. Івануса
ORCID https://orcid.org/0000-0002-9803-588X
ResearcherID P-2026-2016
Scopus Author ID 57193544926

М. М. Михалків

ORCID https://orcid.org/0000-0002-8574-6412

ResearcherID P-2011-2016

Scopus Author ID 57201748668

Тернопільський національний медичний університет імені І. Я. Горбачевського МОЗ Украӥни

\title{
ОСОБЛИВОСТІ ВИКЛАДАННЯ АНАЛІТИЧНОЇ ХІМІЇ ДЛЯ СТУДЕНТІВ ФАРМАЦЕВТИЧНОГО ФАКУЛЬТЕТУ (ЗАОЧНОЇ ФОРМИ НАВЧАННЯ)
}

\author{
I. B. Ivanusa, M. M. Mykhalkiv \\ I. Horbachevsky Ternopil National Medical University
FEATURES OF ANALYTICAL CHEMISTRY TEACHING FOR STUDENTS OF PHARMACEUTICAL FACULTY (EXTRAMURAL EDUCATION)

\begin{abstract}
Анотація. Абітурієнти, які мають освітньо-кваліфікаційний рівень молодшого спеціаліста або бакалавра фармацевтичного спрямування, можуть вступати на фармацевтичний факультет Тернопільського національного медичного університету імені I. Я. Горбачевського МОЗ України на заочну форму навчання і здобувати вищу освіту за спеціальністю 226 «Фармація, промислова фармація».

Аналітична хімія - одна із базових дисциплін у фармацевтичній освіті майбутнього провізора, яка є основою для вивчення всіх інших хімічних дисциплін відповідно до навчальних програм освітньо-кваліфікаційного рівня «Магістр фармації». У своїй структурі аналітична хімія містить три основні розділи: якісний аналіз, кількісний аналіз та фізико-хімічні методи дослідження.

Студенти заочної форми навчання вивчають аналітичну хімію на II курсі, в III та IV семестрах. Згідно з навчальним планом підготовки фахівців освітньо-кваліфікаційного рівня «Магістр фармації», для вивчення курсу аналітичної хімії виділено 10 год лекцій, 36 год практичних занять, 194 год самостійної роботи студентів (СПРС).

Лекції здебільшого мають оглядовий характер, оскільки робиться огляд більш складних питань. Практичні заняття третього семестру присвячені якісному аналізу. Особлива увага приділяється вивченню реакцій виявлення, які включені до Фармакопеі України (фармакопейні), що надалі допомагає кращому засвоєнню фахових дисциплін, зокрема фармацевтичної хімії, токсикологічної та судової хімії, стандартизації лікарських засобів. Практичні заняття четвертого семестру присвячені кількісному аналізу, зокрема титриметричним та фізико-хімічним методам аналізу. Для підвищення професійної орієнтації майбутніх провізорів всі практичні роботи поставлені на аналізі готових лікарських засобів. На семінарській частині занять розглядаються теоретичні основи всіх методів аналізу, які використовуються в аналітичній хімії.

Оскільки 19 червня 2019 р. всі студенти заочної форми навчання фармацевтичного факультету складали ліцензійний інтегрований тестовий іспит «Крок-1. Фармація», то на кожній частині практичного заняття, а також на лекціях, частина часу присвячена вивченню питань, які входять у буклети ліцензійного іспиту «Крок-1. Фармація» за всі роки та бази тестових питань.
\end{abstract}

Ключові слова: фармація; аналітична хімія; заочна форма навчання.

Abstract. Entrants, who have the educational and qualification level of a junior specialist or a bachelor in the pharmaceutical sciences, can enter the pharmaceutical faculty of I. Horbachevsky Ternopil National Medical University to extramural education and receive higher education level in specialty 226 "Pharmacy, Industrial Pharmacy".

Analytical Chemistry is one of the basic disciplines in the pharmaceutical education of the future pharmacist, which is the basis for the study of all other chemical disciplines in accordance with the curriculum of the Master's degree in pharmacy. Analytical Chemistry contains three main parts: qualitative analysis, quantitative analysis, and physical and chemical methods of analysis.

Students of extramural learning study Analytical Chemistry in the second year, in the third and fourth semesters. The course of Analytical Chemistry contains 10 hours of lectures, 36 hours of practical classes, and 194 hours of independent work of students according to the curriculum of educational level "Master of Pharmacy".

Lectures are mostly viewing nature as an overview on the more complex issues. Practical classes of the third semester are dedicated to qualitative analysis. Particular attention is dedicated to the study of pharmacopoeia's reactions (included in the Pharmacopoeia of 
Ukraine), which in further helps to better learning pharmaceutical chemistry, toxicological and forensic chemistry, standardization of medicines. Practical classes of the fourth semester are dedicated to quantitative analysis, including titrimetric and physical-chemical methods of analysis. All practical work students do on the analysis of finished medicines to improve the professional orientation of future pharmacists. The theoretical bases of all methods of analysis used in Analytical Chemistry are discussed on the seminar part.

Since, on June 19, 2019, all students of extramural education of pharmaceutical faculty passed the licensing examination "Krok-1. Pharmacy", so at each part of the practical lesson as well as lectures, part of the time is dedicated to the study of the questions included in the booklets of licensing examination "Krok-1. Pharmacy" for all years and test questions bases.

Key words: pharmacy; analytical chemistry; extramural education.

Вступ. У сучасному світі достатньо часто особи, які мають середню спеціальну освіту і працюють у певній галузі, змушені, на вимогу роботодавця або відповідно до змін у законодавстві, здобувати вищу освіту. Для вирішення цього питання є два напрями: вступати до ВНЗ на денну або заочну форми навчання. Більшість при цьому обирає заочну форму навчання. Перевагою заочної форми навчання $\epsilon$ можливість поєднання роботи і навчання водночас. Однак при цьому студент повинен у проміжках між сесіями багато працювати із літературою, писати контрольні роботи з метою опанування теоретичного матеріалу з дисципліни. На сесії студент опановує вже практичні навички.

На даний час у вищих медичних закладах України заочна форма навчання впроваджена за напрямами підготовки: «Фармація», «Громадське здоров'я», «Медсестринство». У Тернопільському національному медичному університеті імені I. Я. Горбачевського МОЗ України на заочну форму навчання $€$ набір абітурієнтів на всі ці напрями. На фармацевтичному факультеті на заочній формі навчання можуть вчитися особи, які здобули освітньо-кваліфікаційний рівень молодшого спеціаліста або бакалавра фармацевтичного спрямування для здобуття ступеня магістра за спеціальністю 226 «Фармація, промислова фармація».

Дисципліни, які вивчаються студентами, як денної, так і заочної форми навчання, на фармацевтичному факультеті поділяють на базові та фахові. Курс аналітичної хімії є базовим, і при підготовці фахівців у галузі фармації посідає особливе місце $[3,4]$. Це зумовлено, перш за все, тим, що ця дисципліна безпосередньо пов' язана з вивченням цілого ряду інших обов'язкових предметів, серед яких «Фармацевтична хімія», «Основи хімічної метрології», «Стандартизація лікарських засобів», «Технологія ліків», «Фізичні методи аналізу» та ін. $[1,2]$.

Основні вимоги, які висуваються до аналітичної хімії, - це правильність та відтворюваність результатів аналізу, низька межа виявлення, вибірковість, експресність, простота аналізу і можливість його автоматизації. Ці вимоги відображають основні тенденції розвитку аналітичної хімії. Виконання цих вимог можливе за наявності відповідного обладнання, приладів, хімічних реактивів тощо [6].

Аналітичні методи $є$ важливішими при контролі якості різноманітних лікарських форм, створенні та виготовленні нових препаратів, дослідженнях впливу ліків на організм людини тощо. Фармакопея України використовує найбільш ефективні методи аналізу. Тому важко уявити фахівця в галузі фармації, який не має теоретичної бази та не володіє практичними навичками у сфері аналітичної хімії [4].

19 червня 2019 р. відповідно до дати проведення ліцензованих іспитів, затвердженої наказом МО3 України від 11.09.2018 р. № 1647, вперше студенти заочної форми навчання фармацевтичного факультету складали ліцензійний інтегрований тестовий іспит «Крок-1. Фармація» (до 2019 р. іспит був пілотний), метою якого є встановлення відповідності рівня базової компетентності студента мінімально необхідному рівню згідно з вимогами Державних стандартів вищої освіти. Критерій «склав» встановлено на рівні 60,5 \% правильних відповідей наказом МО3 України від 05.10.2016 р. № 1043. Відповідно до змісту іспиту, кількість тестових завдань 3 дисципліни «Аналітична хімія» становить 12-16 \% від загальної кількості тестових завдань, що містяться в буклеті «Крок-1. Фармація» [5]. Впровадження ліцензійного інтегрованого іспиту «Крок-1. Фармація» для студентів заочної форми навчання фармацевтичного факультету вимагає ретельної підготовки з базових дисциплін, що входять до іспиту, в тому числі й аналітичної хімії.

Мета дослідження - вивчити особливості викладання аналітичної хімії для студентів фармацевтичного факультету заочної форми навчання.

Методи дослідження. Для досягнення мети використані теоретичні та емпіричні методи дослідження, зокрема класифікація та систематизація літературних джерел, метод теоретичного аналізу й синтезу, інтерпретація та узагальнення опрацьованих матеріалів для формування висновків.

Результати дослідження. У структурі аналітичної хімії, як однієї з дисциплін, що вивчається студентами заочної форми навчання на фармацевтичному факультеті, виділяють три основні розділи: 
- теоретичні основи аналітичної хімії (застосування закону діючих мас до кислотно-основних, гетерогенних, окисно-відновних рівноваг та рівноваг комплексоутворення) і якісний аналіз йонів (катіонів та аніонів);

- хімічні методи кількісного визначення (гравіметричний і титриметричні методи аналізу);

- фізико-хімічні методи аналізу (оптичні, електрохімічні, хроматографічні): теоретичні основи, випадки й особливості застосування.

Студенти заочної форми навчання вивчають аналітичну хімію на II курсі, в III та IV семестрах. Згідно з навчальним планом підготовки фахівців освітньо-кваліфікаційного рівня «Магістр фармації», для вивчення курсу аналітичної хімії виділено 10 год лекцій, 36 год практичних занять, 194 год самостійної роботи студентів (СПРС). У весняному семестрі I курсу студентам читається одна настановча лекція з аналітичної хімії. На II курсі у кожному семестрі студенти мають по 3 шестигодинних практичних заняття та по 2 лекції.

На першій лекції викладач розглядає не тільки важливість вивчення аналітичної хімії, її роль у фармацевтичній галузі та майбутній освіті провізора, основні типи рівноваг (кислотно-основна, гетерогенна, окисно-відновна, комплексоутворення), а ще й розглядає загальні питання: перелік необхідної літератури для вивчення дисципліни, розташування лекцій та практичних занять, перелік питань, які входять до бази або буклетів «Крок-1. Фармація», графік чергувань на платформі Moodle.

Всі лекції студентам читаються з мультимедійним супроводом, які допомагають кращому сприйняттю викладеного матеріалу та його засвоєнню. На лекцію студенти приходять із лекційним матеріалом, оскільки матеріали підготовки до лекцій розміщені на Web-порталі університету. Викладачі стараються читати лекції у формі діалогу, оскільки більшість студентів вже має середню спеціальну освіту. Обмеженість у часі та великий обсяг матеріалу, який виноситься для розгляду на лекцію, вимагають від викладача дуже чіткої структури і послідовності. Лекції здебільшого мають оглядовий характер, оскільки робиться огляд більш складних питань. Важливим є те, що при викладанні теоретичного матеріалу протягом усієї лекції викладач звертає увагу на ті питання, які входять до переліку «Крок-1. Фармація».

Кожне практичне заняття забезпечене методичними рекомендаціями, матеріалами підготовки до практичного заняття, тестовими завданнями для контролю знань, ситуаційними задачами та методичними вказівками для самостійної роботи студентів.

Практичні заняття третього семестру присвячені якісному аналізу. На першому практичному занятті студенти вивчають I, II, III групи катіонів за кислотно-основною класифікацією, на другому - III, IV, V групи катіонів, на третьому - I, II, III групи аніонів. На кожному занятті студент самостійно проводить якісні реакції на катіони та аніони, після виконання яких він отримує індивідуальний досліджуваний розчин для виявлення в ньому іонів. Після визначення невідомого катіона чи аніона студенти оформляють протоколи та пишуть висновки до кожної практичної роботи.

Особлива увага приділяється вивченню реакцій виявлення, які включені до Фармакопеї України (фармакопейні), що надалі допомагає кращому засвоєнню фахових дисциплін, зокрема фармацевтичної хімії, токсикологічної та судової хімії, стандартизації лікарських засобів.

Практичні заняття IV семестру присвячені кількісному аналізу, зокрема титриметричним та фізико-хімічним методам аналізу. На четвертому занятті студенти вивчають кислотно-основне та осаджувальне титрування, на п'ятому занятті - комплексиметричне та окисно-відновне титрування, на шостому - фізико-хімічні методи аналізу (оптичні, електрохімічні, хроматографічні). Для підвищення професійної орієнтації майбутніх провізорів всі практичні роботи поставлені на аналізі готових лікарських засобів, зокрема кількісне визначення натрію хлориду у фізіологічному розчині проводять аргентометрично, кальцію хлориду в ін'єкціях кальцію хлориду 10 \% - комплексонометрично, вітаміну $\mathrm{B}_{12}$ - спектрофотометрично тощо. Після практичної роботи студенти проводять розрахунок кількісного вмісту активного фармацевтичного інгредієнта у препараті. Цей результат порівнюють із декларованим вмістом, зазначеним у Державній Фармакопеї України.

Перелік практичних робіт складений так, щоб студенти могли засвоїти практичні навички як класичних, так і сучасних методів аналізу, передусім тих, що пропонуються у Фармакопеї.

Відповідно до структури заняття, після практичної частини проходить семінар. На семінарській частині занять третього семестру студенти розглядають теоретичні основи аналітичної хімії, які надалі будуть використані при вивченні хімічних та фізико-хімічних методів аналізу в четвертому семестрі. А також у четвертому семестрі приділяється велика увага титриметричним та фізико-хі- 
мічним методам аналізу, особливо фармакопейним. Окрім того, на семінарській частині заняття частина часу присвячена вивченню питань, які входять у буклети ліцензійного іспиту «Крок-1. Фармація» за всі роки. Разом із студентами активно розбираються правильні відповіді на тестові завдання типу Крок-1, кожного разу наголошуючи на практичній або теоретичній частині заняття.

В кінці кожного заняття студенти пишуть самостійну роботу у формі тестових завдань. Тестові завдання викладачі використовують із бази Крок-1 та буклетів. За умови, якщо студент не набирає достатньої кількості правильних відповідей, він ще раз готується і перескладає ці тести. На нашій кафедрі відсоток правильних відповідей, так само, як і відповідно до наказу МОЗ України від 05.10.2016 р. № 1043, складає 60,5 \% правильних відповідей.

\section{Список літератури}

1. Івануса I. Б. Необхідність поглибленого вивчення фізико-хімічних методів аналізу у фармацевтичній освіті / І. Б. Івануса, М. М. Михалків // Медична освіта. 2016. - № 1. - С. 74-77.

2. Івануса І. Б. Роль розрахункових задач при вивченні аналітичної хімії у фармацевтичній освіті / І. Б. Івануса, М. М. Михалків, А. Є. Демид // Медична освіта. 2015. - № 4. - С. 24-26.

3. Кайдалова Л. Г. Професійна підготовка майбутніх фахівців фармацевтичного профілю у вищих навчальних закладах / Л. Г. Кайдалова. - Х. : НФаУ, 2010. - 364 с.

\section{References}

1. Ivanusa, I.B., \& Mykhalkiv, M.M. (2016). Neobkhidnist pohlyblenoho vyvchennia fizyko-khimichnykh metodiv analizu u farmatsevtychnii osviti [Necessity in-depth study of physical and chemical methods of analysis in the pharmaceutical education]. Medychna osvita - Medical Education, (1), 74-77 [in Ukrainian].

2. Ivanusa, I.B., Mykhalkiv, M.M., \& Demyd, A.Ye. (2015). Rol rozrakhunkovykh zadach pry vyvchenni analitychnoi khimii u farmatsevtychnii osviti [The role of calculation tasks at studying of analytical chemistry in pharmaceutical education]. Medychna osvita - Medical Education, (4), 24-26 [in Ukrainian].

3. Kaidalova, L.H. (2010). Profesiina pidhotovka maibutnikh fakhivtsiv farmatsevtychnoho profiliu u vyshchykh navchalnykh zakladakh [Professional training of future specialists of pharmaceutical profile in higher education institutions]. Kharkiv: NFaU [in Ukrainian].
Ми вважаємо, що розгляд та написання тестових питань з бази та буклетів ліцензійного іспиту «Крок-1. Фармація» на лекціях, та кожній частині практичного заняття, допоможе студентам краще скласти цей іспит наприкінці третього курсу.

Висновки та перспективи подальших досліджень. 1. Аналітична хімія навчає майбутніх провізорів застосовувати набуті знання для аналізу лікарських засобів та хімічних речовин, сформувати аналітичне мислення з метою використання найбільш раціонального методу аналізу для рішення конкретного аналітичного завдання, розробки плану дослідження та виконання експерименту.

2. Розгляд тестових питань з баз та буклетів ліцензійного іспиту «Крок-1. Фармація» на лекціях, кожній частині практичних занять, а також у письмовому контролі, на нашу думку, буде сприяти підвищенню відсотка правильних відповідей на ліцензійному іспиті «Крок-1. Фармація».

4. Копняк Н. І. Застосування інноваційних технологій у навчальному процесі / Н. І. Копняк, Т. В. Красильник // Сучасні інформаційні технології та інноваційні методики навчання у підготовці фахівців: методологія, теорія, досвід, проблеми : зб. наук. праць. - К. ; Вінниця : ДОВ Вінниця, 2000. - С. 379-380.

5. Крок-1 [Електронний ресурс]. - Режим доступу : https://www.testcentr.org.ua/uk/krok-1.

6. Лебедева М. И. Аналитическая и органическая химии (часть 4) : учебное пособие / М. И. Лебедева, И. А. Анкудимова, М. А. Свиряева. - Тамбов : Изд-во ФГБОУ ВПО «ТГТУ», 2014. - 197 с.

4. Kopniak, N.I., \& Krasylnyk, T.V. (2000). Zastosuvannia innovatsiinykh tekhnolohii u navchalnomu protsesi [Application of innovative technologies in the educational process]. Suchasni informatsiini tekhnolohii ta innovatsiini metodyky navchannia u pidhotovtsi fakhivtsiv: metodolohiia, teoriia, dosvid, problemy: [zb. nauk. prats] [Modern information technologies and innovative teaching methods in the training of specialists: methodology, theory, experience, problems]. Kyiv-Vinnytsia: DOV Vinnytsia [in Ukrainian].

5. Krok-1. Retrieved from: https://www.testcentr.org.ua/ uk/krok-1.

6. Lebedeva, M.I., Ankudimova, M.A., \& Sviryaeva, I.A. (2014). Analiticheskaya i organicheskaya khimii (chast 4) [Analytical and organic chemistry (part 4)]. Tambov: FGBOU VPO “TGTU” [in Russian]. 